International Journal of Social Sciences and Humanities
Available online at http://sciencescholar.us/journal/index.php/ijssh
Vol. 1 No. 3, December 2017, pages: $1 \sim 7$
e-ISSN: 2550-7001, p-ISSN: 2550-701X
http://dx.doi.org/10.21744/ijssh.v1i3.47

\title{
Cashless System of Colleges in India
}

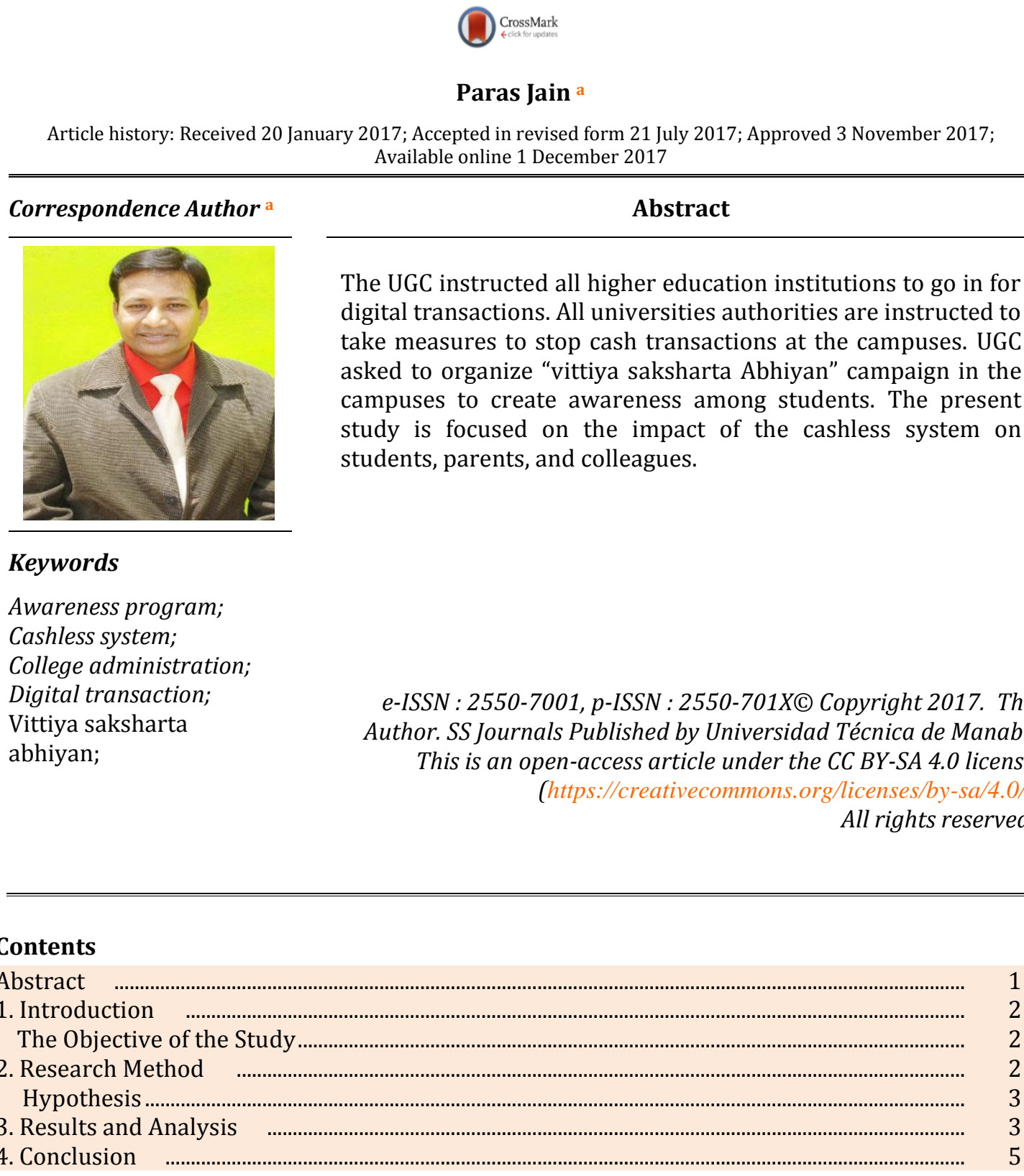

a Director, Silicobyte Katni Degree College, Dikshabhumi Campus , Adharkap, Katni (M.P) -483501 


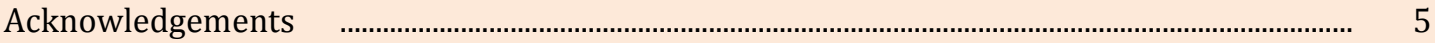

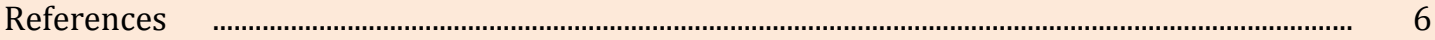

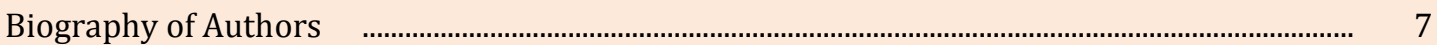

\section{Introduction}

UGC issued circular asking educational institutes to move away from cash-based transactions and adopt online payment modes. The universities have forwarded the circular to all institutes, affiliated colleges to follow UGC guideline. The colleges have to go cashless. Some colleges have already adopted ways to go cashless. Others will have to follow according to other favorable arrangements.

Most of the College administrators said that today's students are very tech savvy. They will have no problem adapting to the new system of transaction. Online payment will be made fees payment process convenient for parents and management. Parents don't have to stand in a queue of college and colleges will not have to stand in queues of the bank. Most of the students could easily switch to cashless transactions only economically weaker sections of society would face the problem. Some Colleges, universities already switched to cashless transactions for its employees. Salary, student's fees, parking charges, canteen fees, fine and all expenses are making alive. The colleges are instructed to train students on cashless transactions.

IIT's, IIM's have made campus cashless. Online payment as part of the move is enabling students to make easy and quick payments without worrying about carrying loose cash. The facility can be availed at various offline touch points within campus including hostel, canteen, medical store, tea stall, book stall, cycle repairing shop etc. SRCC college of DU was the first college of the country which is fully cashless. For this purpose, college has organized digital fair and students, teachers, food vendors, college administrators were trained for digital payment. The govt. is promoting cashless transaction and had asked institutes to ensure cashless transaction. The ease of conducting financial transactions is the biggest motivator to go digital. It's a safer way when a person is traveling he may transact money. There are enormous benefits of the online transaction, especially in case of emergencies. Without physical presence and at any time transaction is possible. If all transactions are on record, it will be very easy for people to keep track of their spending. Apps are available to make process easy. There is no risk of steel.

There are no. of the students and parents don't know how to make payment. The bigger fear of cashless system is the risk of identity theft. With the rising incidence of online fraud, the risk of hacking will grow as more people hop on the digital platform. If someone loses money online, process becomes tedious, poor grievance redressed. In this process, a person has to depend on the phone for all transactions, if someone loses it may be great problematic. Another drawback is that need to keep constantly changing. India has a low internet penetration of $34.8 \%$ according to internet live stats and only $26.3 \%$ of all mobile phone users have smartphones. It's a problem for older parents i.e., grandparents. Some students depend on grandparents as a financial source. This system is a challenge for tech-unfriendly people.

\section{The objective of the Study:}

To find view of college students locality wise with respect to cashless system in college To find view of college student's parents with respect to cashless system in college To find view of college administrators with respect to cashless system in college

\section{Research Method}

Descriptive survey method was adopted for the study. 20 colleges, 200 parents, and 200 students were selected for the study. 50\% colleges, students, and parents were from Govt. College and $50 \%$ were from private colleges. To collect their view a self-prepared questionnaire were used. Collected data was tabulated, converted into a percentage and comparatively analyzed. 


\section{Hypothesis:}

There is no significant difference between rural and urban students with respect to impact of cashless system

There is no significant influence of cashless system on college student's parents

There is no significant influence of cashless system on college administrators

\section{Results and Analysis}

Table-1: Status of Impact of Cashless system in Colleges on Students

\begin{tabular}{|c|c|c|}
\hline \multirow{2}{*}{ Locality } & \multicolumn{2}{|c|}{ No. of Students \% } \\
\cline { 2 - 3 } & $\begin{array}{c}\text { Easiness with Cashless } \\
\text { System }\end{array}$ & $\begin{array}{c}\text { Difficulties with Cashless } \\
\text { System }\end{array}$ \\
\hline Rural & 27 & 73 \\
\hline Urban & 68 & 32 \\
\hline
\end{tabular}

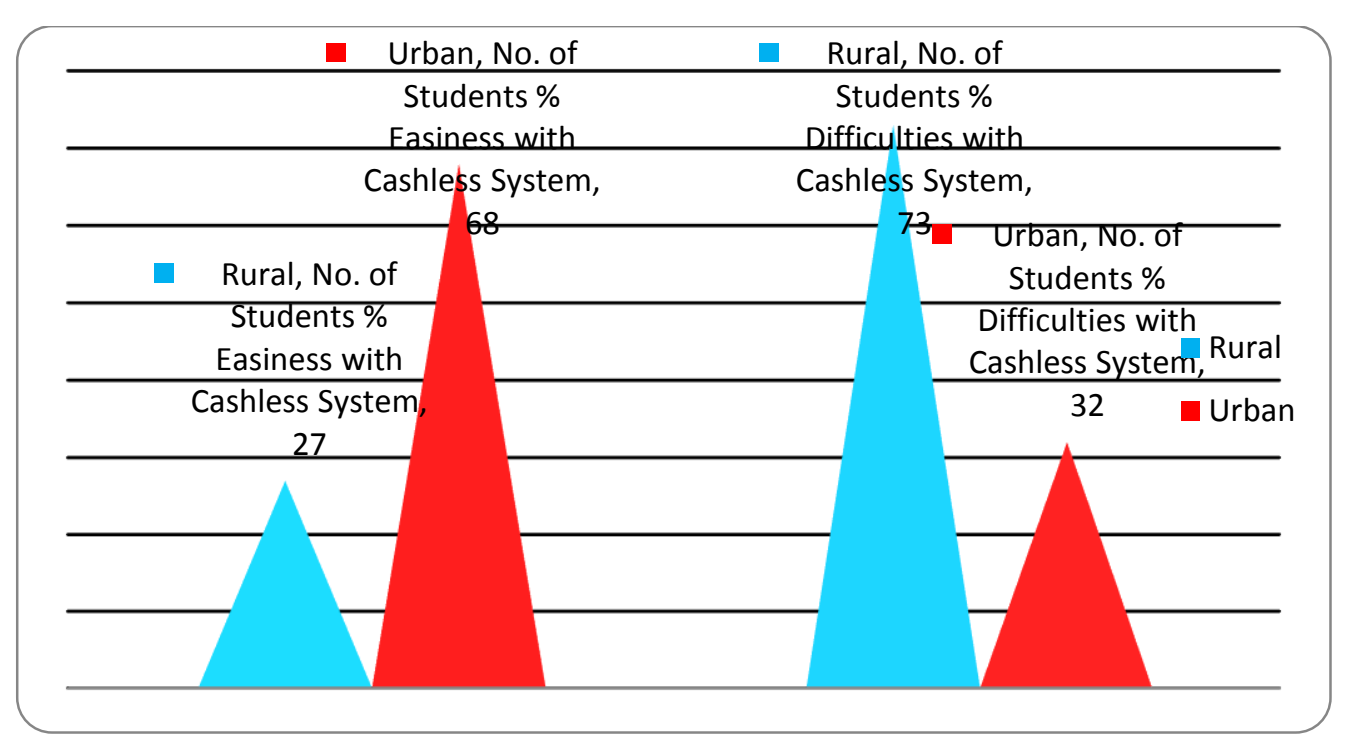

Chart-1: Status of Impact of Cashless system in Colleges on Students

Table-2: Status of Impact of Cashless system in Colleges on Parents

\begin{tabular}{|c|c|c|}
\hline \multirow{2}{*}{ College Category } & \multicolumn{2}{|c|}{ No. of Students \% } \\
\cline { 2 - 3 } & $\begin{array}{c}\text { Easiness with Cashless } \\
\text { System }\end{array}$ & $\begin{array}{c}\text { Difficulties with } \\
\text { Cashless System }\end{array}$ \\
\hline Govt. College & 48 & 52 \\
\hline Private College & 59 & 41 \\
\hline
\end{tabular}

Jain, P. (2017). Cashless system of colleges in India. International Journal of Social Sciences and Humanities, 1(3), 1-7. https://doi.org/10.29332/ijssh.v1n3.47 


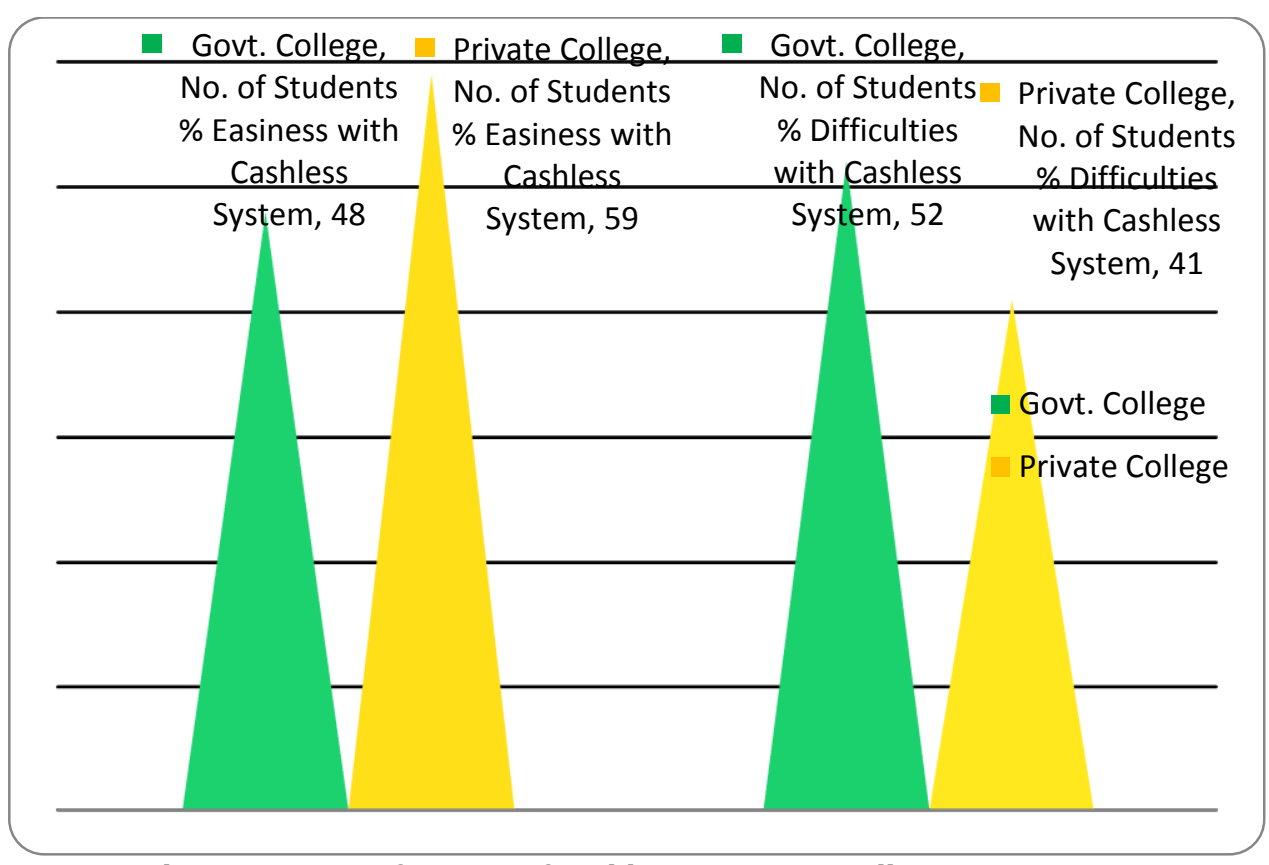

Chart-2: Status of Impact of Cashless system in Colleges on Parents

Table-3: Status of Impact of Cashless system in Colleges on College Administrators

\begin{tabular}{|c|c|c|}
\hline \multirow{2}{*}{ College Category } & \multicolumn{2}{|c|}{ No. of Students \% } \\
\cline { 2 - 3 } & $\begin{array}{c}\text { Easiness with } \\
\text { Cashless } \\
\text { System }\end{array}$ & $\begin{array}{c}\text { Difficulties with } \\
\text { Cashless System }\end{array}$ \\
\hline Govt. College & 86 & 14 \\
\hline Private College & 67 & 33 \\
\hline
\end{tabular}

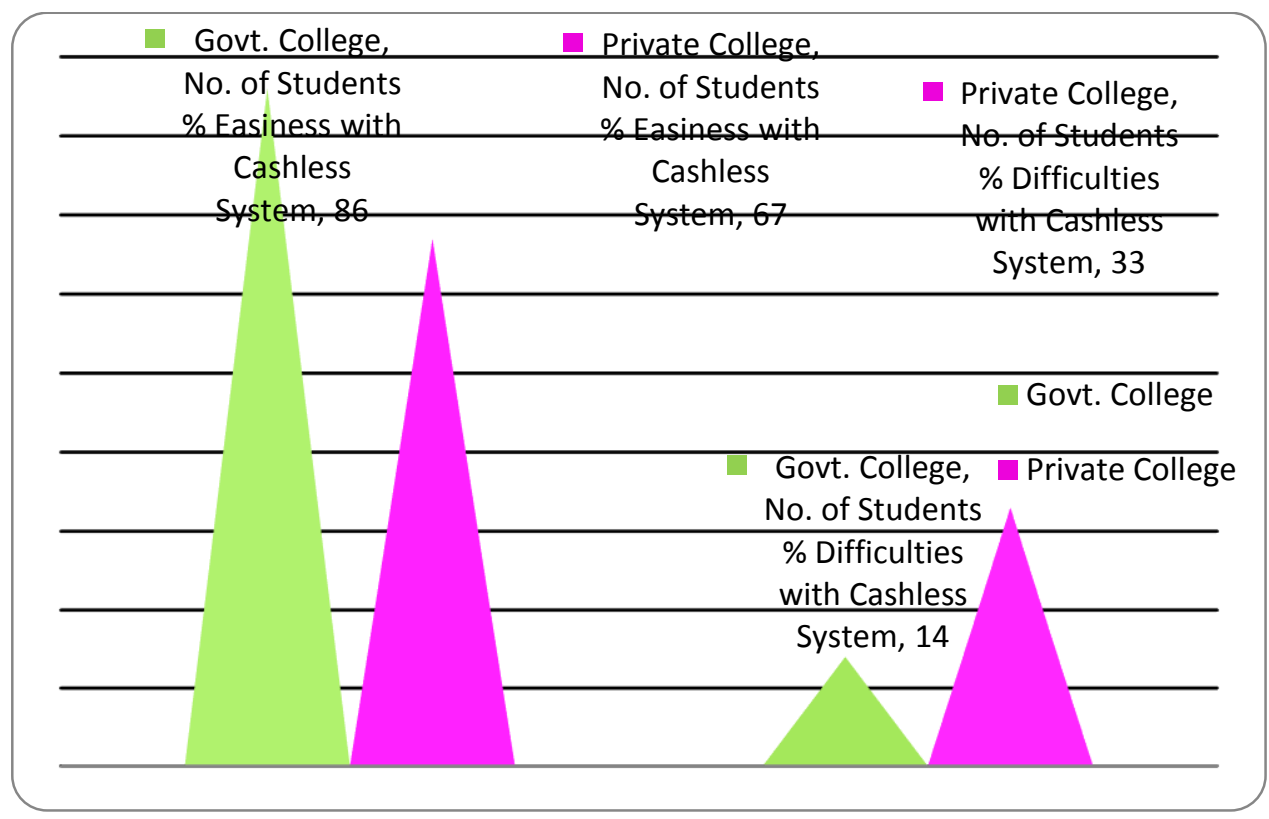

Chart-3: Status of Impact of Cashless system in Colleges on College Administrators 
Locality-wise comparison data indicates that in an urban area $68 \%$ students and in rural area $27 \%$ students feel easiness with the cashless system while $73 \%$ rural and $32 \%$ urban students have difficulties. The study shows difficulties of rural students hence, hypothesis 1 there is no significant difference between rural and urban students with respect to the impact of the cashless system is rejected.

Parents view in this context exhibits consent of $48 \%$ parents of govt. and $59 \%$ parents of private college students. Difficulties were expressed by $52 \%$ of govt. college student's parents and $41 \%$ of private college student's parents. Thus hypothesis 2 there is no significant influence of cashless system on college student's parents is rejected.

College administrator's view indicates that $86 \%$ govt. college administrators and $67 \%$ private college administrators expressed their easiness with the cashless system while difficulties were showed by $14 \%$ govt. and $33 \%$ private college administrators. Thus hypothesis 3 there is no significant influence of cashless system on college administrators is rejected.

\section{Conclusion}

There are many difficulties observed in case of rural students and parents. Poor students also have problems as they don't have a bank account and have fear of un security of money. They are not IT literate, unknown for useful apps, the net banking system. Some urban parents also have difficulties regarding digital payment. However, people are trying to change and adopting the cashless system. Due to so many types of undeclared fees, difficulties of rural students, declaration of turn over amount are problems of private colleges. To make transparent and powerful economy it is an important initiative and all colleges should implement effectively.

\section{Acknowledgement}

The author thanks to the editor for considering the present study to be published in International Journal of Social Sciences and Humanities. ScienceScholar Publishing. 


\section{References}

1. Adetunji, A. T., Adetunji, A. V., Adeleke, E. O., \& Madubuike, S. C. (2017). Deregulation: The Effect of Market-led Approach to Nigerian Universities Management. International Journal of Social Sciences and Humanities (IJSSH), 1(1), 1-8. View in (Google Scholar)

2. Amerta, I. M. S. (2017). The Role of Tourism Stakeholders at Jasri Tourism Village Development, Karangasem Regency. International Journal of Social Sciences and Humanities (IJSSH), 1(2), 20-28. View in (Google Scholar)

3. Ansari, M. N. (2017). List of Recently Published Quality Research Papers. Imperial Journal of Interdisciplinary Research, 3(8). view in (Scopus)

4. Astawa, I. N., Mantra, I. B. N., \& Widiastuti, I. A. M. S. (2017). Developing Communicative English Language Tests for Tourism Vocational High School Students. International Journal of Social Sciences and Humanities (IJSSH), 1(2), 58-64. View in (Google Scholar)

5. Basak, A., \& Khanna, K. (2017). A Study on the Selection Criteria of Different Hotels of Delhi NCR in Accordance to the HR Policies and Market Trends. International Journal of Social Sciences and Humanities (IJSSH), 1(1), 27-38. View in (Google Scholar)

6. Billaiya, R., Malaiya, S., \& Parihar, K. S. (2017). Impact of Socio Economic Trends on Students in Quality Education System. International Journal of Social Sciences and Humanities (IJSSH), 1(1), 16-20. View in (Google Scholar)

7. Caldwell, R. R., Dave, R., \& Steinhardt, P. J. (1998). Cosmological imprint of an energy component with general equation of state. Physical Review Letters, 80(8), 1582. view in (Scopus)

8. Cedeño, M. L. D., Arteaga, M. G. D., Pérez, A. V., \& Arteaga, M. L. D. (2017). Regulatory Framework for Renewable Energy Sources in Ecuador Case Study Province of Manabí. International Journal of Social Sciences and Humanities (IJSSH), 1(2), 29-42. View in (Google Scholar)

9. Gámez, M. R., Pérez, A. V., Será, A. S., \& Ronquillo, Z. M. (2017). Renewable Energy Sources and Local Development. International Journal of Social Sciences and Humanities (IJSSH), 1(2), 10 19. View in (Google Scholar)

10.Ghosh, C. (2017). A Study on-Evaluating Marketing Strategies Adopted by Home Appliance for Economic Development in India. International Journal of Social Sciences and Humanities (IJSSH), 1(1), 9-15. View in (Google Scholar)

11. Maba, W. (2017). Teacher's Perception on the Implementation of the Assessment Process in 2013 Curriculum. International Journal of Social Sciences and Humanities (IJSSH), 1(2), 1-9. View in (Google Scholar)

12. Maba, W., \& Mantra, I. B. N. (2017). An Analysis of Assessment Models Employed by The Indonesian Elementary School Teachers. International Journal of Social Sciences and Humanities (IJSSH), 1(1), 39-45. View in (Google Scholar)

13.Suparsa, I. N., Mantra, I. B. N., \& Widiastuti, I. A. M. S. (2017). Developing Learning Methods of Indonesian as a Foreign Language. International Journal of Social Sciences and Humanities (IJSSH), 1(2), 51-57. View in (Google Scholar)

14.Suryasa, I. W., Prayoga, I. G. P. A., \& Werdistira, I. W. A. (2017). An Analysis of Students' Motivation Toward English Learning As Second Language Among Students In Pritchard English Academy (PEACE). International Journal of Social Sciences and Humanities (IJSSH), 1(2), 43 50. View in (Google Scholar)

15.Tapper, T., \& Palfreyman, D. (2010). Oxford, the collegiate university: Conflict, consensus and continuity (Vol. 34). Springer Science \& Business Media. view in (Scopus) 
16. Thorne, R. S. W., \& Helm, E. (1957). Contribution to the study of over foaming beer. Journal of the Institute of Brewing, 63(5), 415-435. view in (Scopus)

\section{Biography of Author}

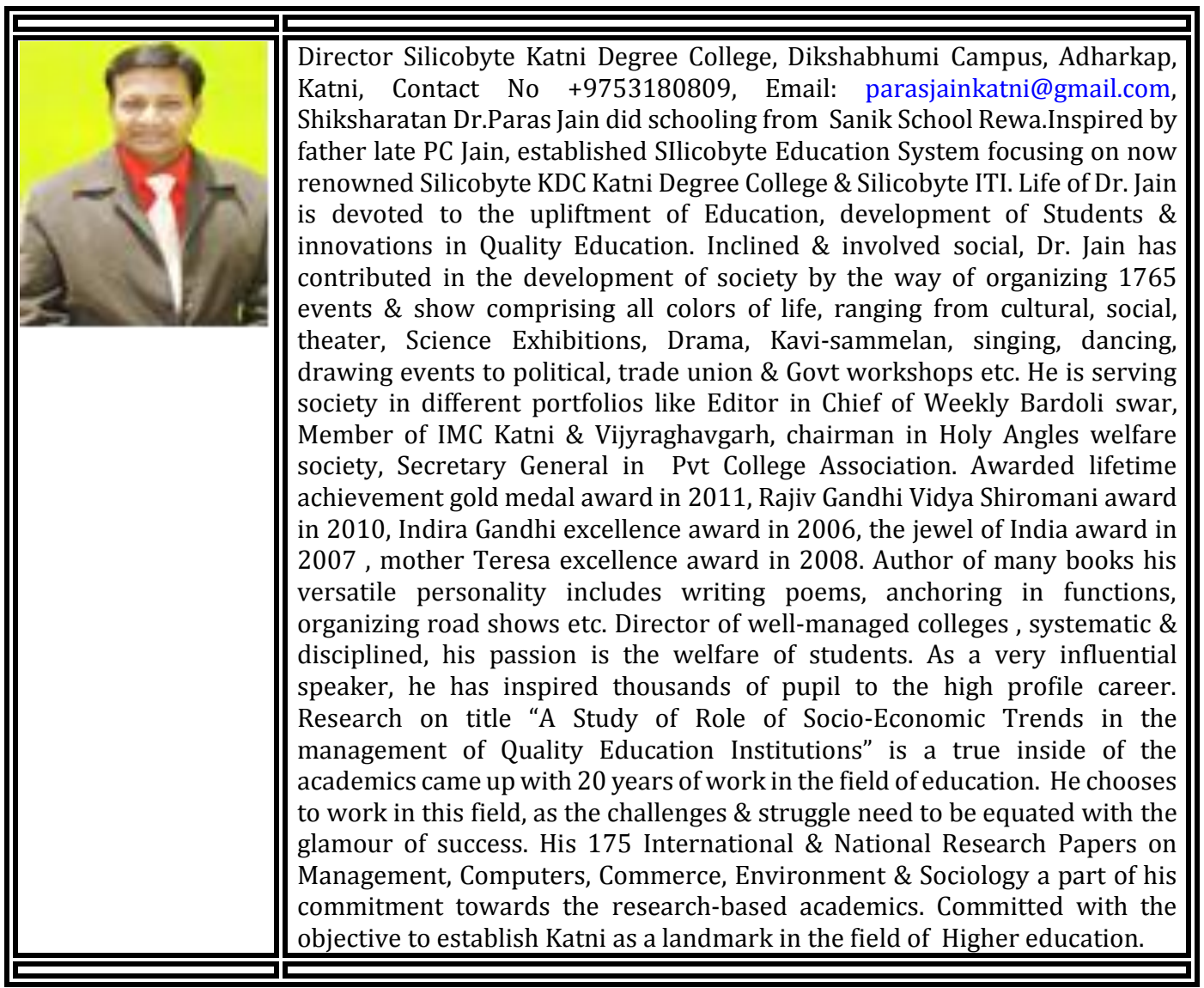

Jain, P. (2017). Cashless system of colleges in India. International Journal of Social Sciences and Humanities, 1(3), 1-7. https://doi.org/10.29332/ijssh.v1n3.47 